Рекомендована д. біол. наук, проф. Л. С. Фірою

УДК 543.42.062:615.453.42

DOI 10.11603/2312-0967.2017.2.7894

\title{
РОЗРОБКА ТА ВАЛІДАЦІЯ СПЕКТРОФОТОМЕТРИЧНОЇ МЕТОДИКИ КІЛЬКІСНОГО ВИЗНАЧЕННЯ ЕНІСАМІУМУ ЙОДИДУ В КАПСУЛАХ
}

\author{
(c) О. В. Бурмака, С. М. Гуреєва, В. М. Маргітич
}

\author{
ПАТ «Фармак», Київ \\ o.burmaka@farmak.ua
}

\begin{abstract}
Мета роботи. Розробити методику кількісного визначення енісаміуму йодиду в капсулах із застосуванням методу абсорбційної спектрофотометрії в ультрафріолетовій області.

Матеріали і методи. Використано стандартний зразок енісаміум йодиду та зразок готової лікарської фрорми виробництва ПАТ «Фармак». У ході роботи було встановлено оптимальну робочу концентрацію енісаміуму йодиду 0,02 мг/мл. Дослідження проводили із застосуванням спектрофотометра «Specord 250 Plus».

Результати й обговорення. Продемонстровано, що оптимальна довжина хвилі при визначенні становить 267 нм. Вивчено валідаційні характеристики методики в діапазоні 0,016-0,024 мг/мл (80-120\%): специорічність, правильність, прецизійність, лінійність, діапазон застосування, робасність, внутрішньолабораторна прецизійність відповідно до рекомендацій Міжнародної коноеренції з гармонізації.

Коефіцієнт кореляції (r) між введеним та знайденим значенням для енісаміуму йодиду становить 0,99996, а відносний довірчий інтервал $\left(\Delta_{z}\right) 0,23 \%$.

Підтверджено стабільність розчинів при їх зберіганні при кімнатній температурі протягом 48 годин.

Висновки. Розроблено спектрофотометричну методику кількісного визначення енісаміуму йодиду в капсулах, експериментально доведено, що вона придатна для контролю якості капсул енісаміуму йодиду.
\end{abstract}

Ключові слова: енісаміум йодид; капсули; кількісне визначення; метод спектрофотометрії; валідація.

Вступ. Енісаміум йодид (N-метил-4-бензилкарбамідопіридинію йодид), структурна фрормула якого наведена на рисунку $1, €$ антивірусним хіміотерапевтичним засобом, що застосовується для лікування грипу та ГРВІ [1, 2]. Відповідно до європейських та українських підходів нормування, відхилення кількісного вмісту активного фрармацевтичного інгредієнту (АФІ) має складати \pm 5 \% від заявленої кількості [3, 4].

Оскільки у фаховій літературі не описано методики контролю енісаміуму йодиду з використанням спектрофотометрії, виникає необхідність її розробки та валідації.

Відповідно до рекомендацій ICH Q2R [5], аналітична методика має бути валідована за наступними характеристиками: специфічність, правильність, прецизійність, лінійність, діапазон застосування, робасність, внутрішньолабораторна прецизійність.

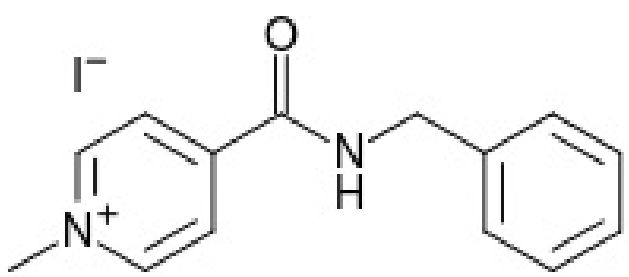

Рис. 1. Структурна фрормула енісаміуму йодиду.
Методи дослідження. Об'єктом дослідження слугували капсули енісаміуму йодиду (Амізон®Макс, с. 10916, виробництва ПАТ «Фармак»).

Для розробки методики та ії валідації було використано наступне обладнання: спектрофотометр «Specord 250 Plus» (Німеччина), ваги електронні «Mettler Toledo AB54S» (Швейцарія) та мірний посуд класу А фрірми «Simax» (Чехія). Застосовано хлористоводневу кислоту виробництва Merck (Німеччина; кат. № 113386) та воду очищену, яку отримано з установки Milli Q, виробництва Millipore Corporation (Hiмеччина) та стандартний зразок енісаміуму йодиду виробництва ПАТ «Фармак», серія 07-16.

Статистичну обробку результатів проводили відповідно до вимог Державної Фармакопеї України (ДФУ) та Європейської фрармакопеї [6, 7].

Результати й обговорення. Встановлено, що енісаміум йодид має два максимуми поглинання: при довжинах хвиль 223 та 267 нм. Ультрафріолетовий спектр енісаміуму йодиду наведено на рисунку 2.

У випадку, коли речовина має більше одного максимуму поглинання, рекомендовано вибирати більшу довжину хвилі [8], в даному випадку - 267 нм. Як розчинник використано 0,1 М розчин хлористоводневої кислоти.

Відповідно до розробленої методики проводили вимірювання випробовуваного розчину та розчину

ISSN 2312-0967. Фармацевтичний часопис. 2017. № 2 
Absorbance

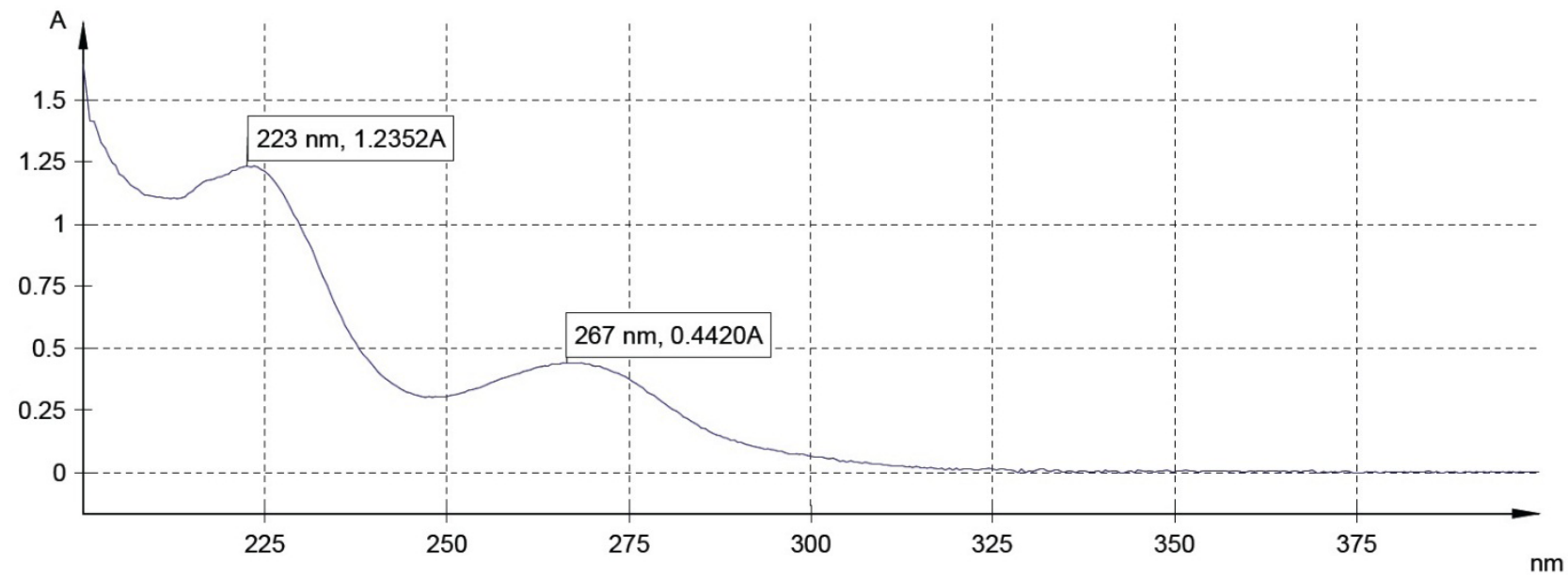

Рис. 2. УФ-спектр енісаміуму йодиду.

порівняння (концентрація обох становила 0,02 мг/мл) у кюветі 3 товщиною шару 10 мм. Як компенсаційний розчин застосовано розчинник $(0,1 \mathrm{M}$ розчин хлористоводневої кислоти).

Для підтвердження специфрічності методики було приготовано розчин допоміжних речовин, що входять до складу препарату, та розчин основних домішок, які можуть бути присутніми, виходячи з результатів вивчення стабільності у готовій лікарській фрормі (ГЛФ), з подальшою оцінкою систематичної похибки $\left(\delta_{\text {noise, }} \%\right)$.

Приготування розчину допоміжних речовин проводили аналогічно до приготування випробовуваного розчину. Спектр розчину плацебо, розчину домішок та розчину порівняння наведено на рисунку 3.

Дані щодо специфічності методики кількісного визначення енісаміуму йодиду наведено в таблиці 1.

Із наведених у таблиці 1 даних випливає, що абсорбція допоміжних речовин та домішок при довжині хвилі 267 нм є незначною і не перевищує критерій прийнятності.

Вивчення лінійності проводили на модельних сумішах, в яких концентрація енісаміуму йодиду лінійно змінювалася в діапазоні від 80 до $120 \%$ (0,016 0,024 мг/мл) відносно номінальної концентрації енісаміуму йодиду у випробовуваному розчині.

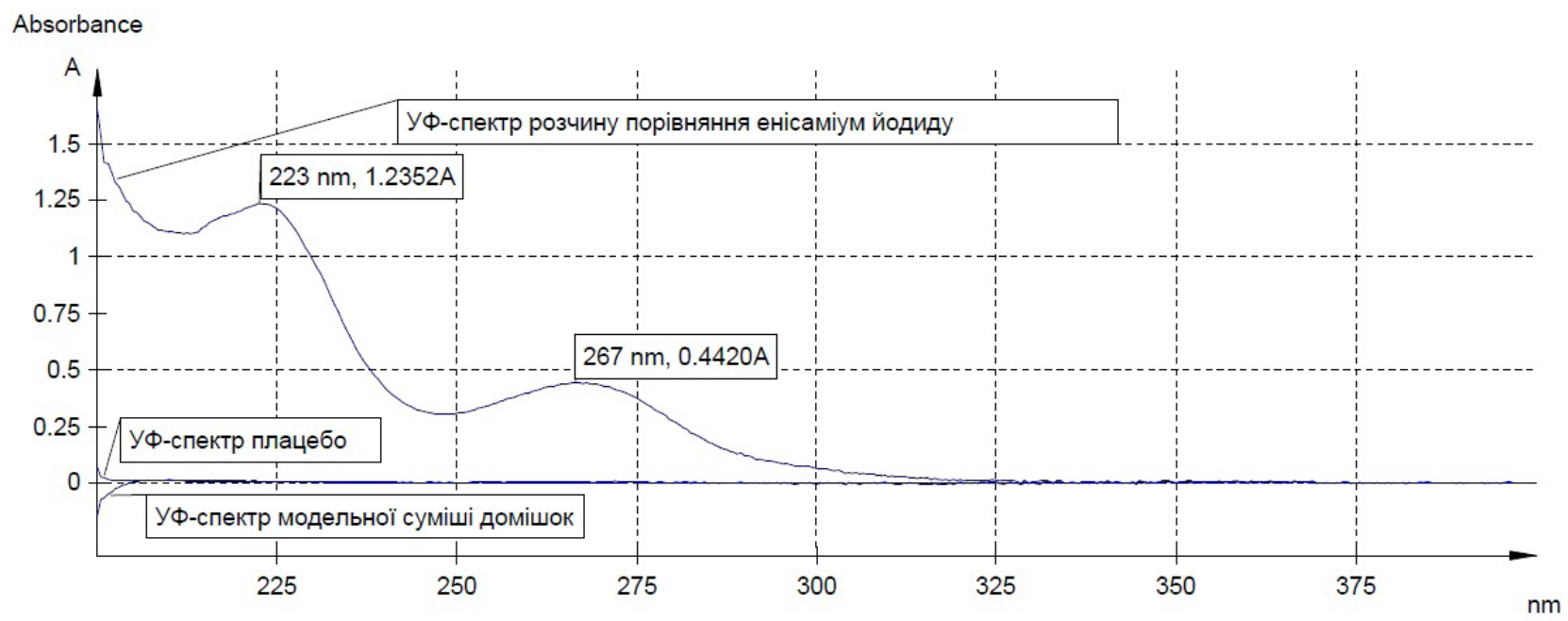

Рис. 3. УФ-спектр розчину плацебо, розчину домішок та розчину порівняння.

Таблиця 1. Специфічність методики кількісного визначення енісаміуму йодиду

\begin{tabular}{|c|c|c|c|c|}
\hline $\begin{array}{c}\text { Абсорбція плацебо } \\
\left.\text { (А } \text { ( }_{\text {PLACEBO }}\right)\end{array}$ & $\begin{array}{l}\text { Абсорбція розчину } \\
\text { домішок ГЛФ ( } \text { ІІмРS })\end{array}$ & $\begin{array}{c}\text { Абсорбція розчину } \\
\text { порівняння }\left(\mathrm{A}_{\mathrm{RS}}\right)\end{array}$ & $\begin{array}{c}\text { Знайдене значення } \\
\frac{A_{\text {FLACEBO }}+A_{\text {IMFS }}}{A_{\text {RS }}} \times 100\end{array}$ & $\begin{array}{c}\text { Критерій } \\
\text { прийнятності }\end{array}$ \\
\hline 0,0003 & 0,0001 & 0,4419 & $0,09 \%$ & $\begin{array}{c}\text { Не більше } \\
0,5 \% \\
\end{array}$ \\
\hline
\end{tabular}

ISSN 2312-0967. Pharmaceutical review. 2017. № 2 
Аналіз лікарських препаратів

\section{Analysis of drugs}

Розрахунок параметрів лінійної залежності проводили методом найменших квадратів [9]. Графрік лінійної залежності наведено на рисунку 4.

Метрологічні характеристики лінійної залежності відповідають вимогам прийнятності, що рекомендовані ДФУ [10]; дані наведено в таблиці 2.

Результати аналізу модельних сумішей енісаміуму йодиду та їх статистичне опрацювання наведено в таблиці 3.

Точність вивчалася на двох рівнях: збіжність (повторюваність) та внутрішньолабораторна прецизійність.

Збіжність оцінювали, аналізуючи в умовах методики розчин порівняння та 6 випробовуваних розчинів, приготованих із однієї серії препарату, а внутрішньолабораторна прецизійність підтверджувалася іншим аналітиком, аналізуючи таку ж кількість зразків тієї ж серії препарату наступного дня.
Результати перевірки точності аналітичної методики наведено в таблиці 4.

Як видно із даних таблиці 4, відносне стандартне відхилення (RSD) отриманих результатів для першого та другого аналітика, а також відносна різниця середніх значень результатів не перевищує 2,0 \%, що свідчить про належну повторюваність результатів.

Правильність оцінювали, аналізуючи 9 модельних розчинів, які готували шляхом розчинення АФІ енісаміуму йодиду 3 концентраціями 80 \%, $100 \%$ та $120 \%$ відносно номінальної концентрації енісаміуму йодиду у випробовуваному розчині з додаванням плацебо (у трьох паралелях для кожного концентраційного рівня).

Отримані результати представлено в таблиці 5.

Відносне стандартне відхилення між результатами для одного концентраційного рівня становить не більше $2,0 \%$.

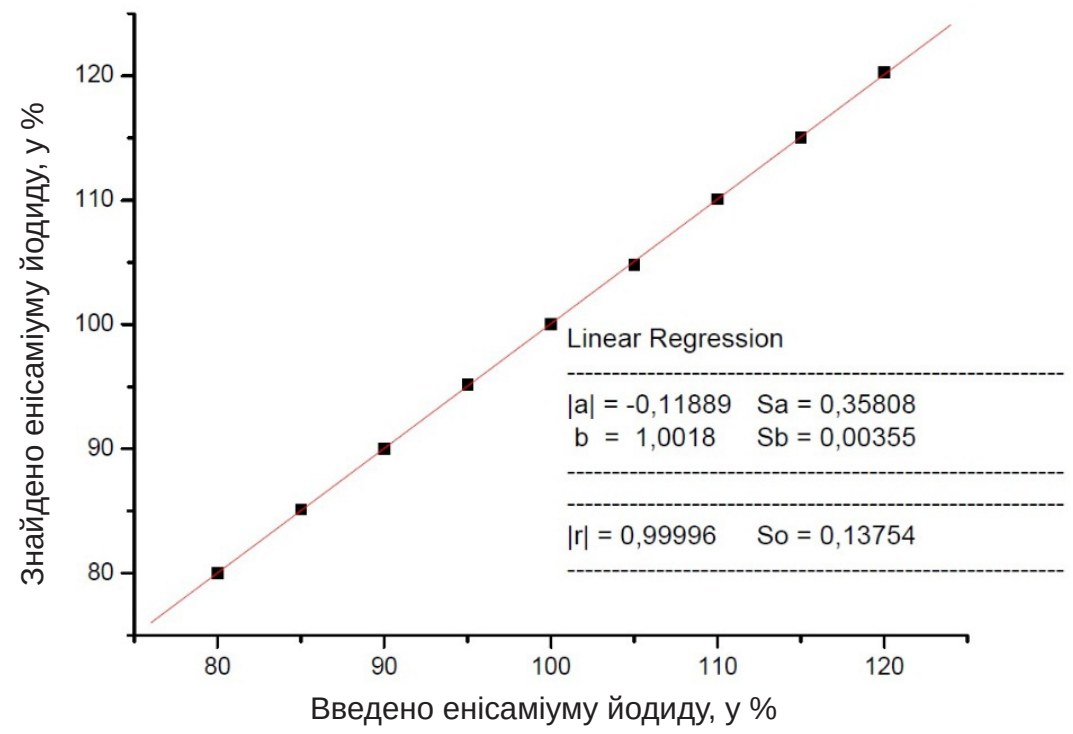

Рис. 4. Грасрік лінійної залежності абсорбції від концентрації енісаміуму йодиду (в нормалізованих координатах).

Таблиця 2. Метрологічні характеристики лінійної залежності абсорбції енісаміуму йодиду від концентрації

\begin{tabular}{|c|c|c|c|}
\hline Величина & Значення & $\begin{array}{c}\text { Критерії прийнятності параметрів лінійної } \\
\text { залежності }\end{array}$ & Висновки \\
\hline $\mathrm{b}$ & 1,0018 & - & - \\
\hline $\mathrm{s}_{\mathrm{b}}$ & 0,00355 & - & відповідає \\
\hline$|\mathrm{a}|$ & 0,11889 & $\leq 2,6$ & - \\
\hline $\mathrm{s}_{\mathrm{a}}$ & 0,35808 & - & - \\
\hline $\mathrm{s}_{0}$ & 0,13754 & - & відповідає \\
\hline $\mathrm{s}_{0} / \mathrm{b}$ & 0,13729 & $\geq 0,84$ & відповідає \\
\hline$|\mathrm{r}|$ & 0,99996 & $\geq 0,99981$ & \\
\hline
\end{tabular}

Примітки:

b - кутовий коефріцієнт для розрахованої регресійної прямої;

$\mathrm{S}_{\mathrm{b}}$ - тангенс кута нахилу для розрахованої регресійної прямої;

$|\mathrm{a}|$ - вільний член лінійної залежності для розрахованої регресійної прямої;

$\mathrm{s}_{\mathrm{a}}$ - стандартне відхилення вільного члена лінійної залежності для розрахованої регресійної прямої;

$\mathrm{s}_{0}$ - залишкове стандартне відхилення;

$|\mathrm{r}|$ - коесріцієнт кореляції між введеним та знайденим значенням для енісаміум йодиду.

ISSN 2312-0967. Фармацевтичний часопис. 2017. № 2 
Таблиця 3. Результати аналізу модельних сумішей та їх статистичне опрацювання для кількісного визначення енісаміуму йодиду

\begin{tabular}{|c|c|c|c|}
\hline \multirow[b]{2}{*}{$\begin{array}{c}\text { № } \\
\text { зразка }\end{array}$} & \multicolumn{3}{|c|}{ Концентрація енісаміуму йодиду } \\
\hline & $\begin{array}{c}\text { у модельній суміші відносно } \\
\text { розчину порівняння, \% } \\
\qquad X_{i}=\frac{C_{i}}{C_{s}} \times 100\end{array}$ & $\begin{array}{c}\text { знайдена на підставі величини } \\
\text { абсорбції, \% } \\
\qquad Y_{i}=\frac{S_{i}}{S_{s}} \times 100\end{array}$ & $\begin{array}{c}\text { розрахована щодо його } \\
\text { введеної кількості, \% } \\
Y_{i}=\frac{S_{i}}{S_{s}} \times 100\end{array}$ \\
\hline 1 & 80,00 & 80,00 & 100,01 \\
\hline 2 & 85,00 & 85,13 & 100,15 \\
\hline 3 & 90,00 & 90,03 & 100,03 \\
\hline 4 & 95,00 & 95,18 & 100,18 \\
\hline 5 & 100,00 & 100,02 & 100,02 \\
\hline 6 & 105,00 & 104,80 & 99,81 \\
\hline 7 & 110,00 & 110,07 & 100,06 \\
\hline 8 & 115,00 & 115,05 & 100,05 \\
\hline 9 & 120,00 & 120,27 & 100,23 \\
\hline \multicolumn{3}{|r|}{ Середнє, Z\% } & 100,06 \\
\hline \multicolumn{3}{|c|}{ Відносне стандартне відхилення, RSD z \% } & 0,12 \\
\hline \multicolumn{3}{|c|}{$\begin{array}{r}\text { Довірчий інтервал збіжності результатів } \\
\Delta_{z} \%=\mathrm{t}(95 \%, 8) \times \mathrm{RSD}_{\mathrm{z}}=1,8595 \times 0,12=\end{array}$} & 0,23 \\
\hline \multicolumn{3}{|c|}{$\begin{array}{r}\text { Критичне значення для збіжності результатів } \\
\qquad \Delta_{z} \% \leq \Delta_{\mathrm{As}}\left(\Delta_{\mathrm{As}}=1,6 \%\right)\end{array}$} & $\begin{array}{l}\text { Виконується } \\
(0,23<1,60)\end{array}$ \\
\hline \multicolumn{3}{|r|}{ Систематична похибка $\delta=\mid Z$ - 100| } & 0,06 \\
\hline \multicolumn{3}{|c|}{$\begin{array}{r}\text { Критерій незначущості систематичної похибки } \\
\qquad \delta \leq 0,32 \times \Delta_{\text {As }}\end{array}$} & $\begin{array}{l}\text { Виконується } \\
(0,06<0,51)\end{array}$ \\
\hline \multicolumn{3}{|c|}{ Загальний висновок щодо методики: } & Коректна \\
\hline
\end{tabular}

Таблиця 4. Результати перевірки точності методики визначення енісаміуму йодиду

\begin{tabular}{|c|c|c|}
\hline \multirow{2}{*}{ № зразка } & Знайдений вміст енісаміуму йодиду $(\mathrm{X}), \%$ від заявленого вмісту \\
\cline { 2 - 3 } & 1-й аналітик & 2-й аналітик \\
\hline 1 & 99,9 & 99,4 \\
\hline 2 & 99,1 & 99,6 \\
\hline 3 & 98,8 & 99,6 \\
\hline 4 & 99,9 & 99,2 \\
\hline 5 & 100,0 & 100,0 \\
\hline 6 & 99,6 & 99,7 \\
\hline Середнє & 99,6 & 0,4 \\
\hline RSD,$\%$ & 0,5 & 0,4 \\
\hline RSD внутрішньолабораторної \\
прецизійність, \%
\end{tabular}

Правильність аналітичної методики знаходиться в межах критерію 98,0 - 102,0 \%.

Робасність аналітичної методики визначалася щодо стабільності випробовуваних розчинів та надійності процедури вимірювання: зміна довжини хвилі детектування та варіювання складу компенсаційного розчину.

Експериментально встановлено, що випробовувані розчини стабільні протягом 48 год при їх зберіганні за кімнатної температури.

ISSN 2312-0967. Pharmaceutical review. 2017. № 2 
Аналіз лікарських препаратів Analysis of drugs

Таблиця 5. Результати аналізу вивчення правильності на 9 модельних сумішах

\begin{tabular}{|c|c|c|c|c|}
\hline № зразка & $\begin{array}{c}\text { Введено відносно концентрації } \\
\text { розчину порівняння, \% } \\
\qquad X_{i}=\frac{C_{i}}{C_{t}} \times 100\end{array}$ & $\begin{array}{c}\text { Знайдено відносно абсорбції } \\
\text { розчину порівняння, \% } \\
Y_{i}=\frac{A_{i}}{A_{s}} \times 100\end{array}$ & $\begin{array}{c}\text { Знайдено відносно } \\
\text { введеного, \% } \\
Z_{i}=\frac{Y_{i}}{X_{i}} \times 100\end{array}$ & $\begin{array}{c}\operatorname{RSD}\left(Z_{i}\right) \\
\%\end{array}$ \\
\hline 1 & 80,0 & 81,15 & 101,43 & \multirow{3}{*}{0,8} \\
\hline 2 & 80,0 & 80,54 & 100,67 & \\
\hline 3 & 80,0 & 79,84 & 99,80 & \\
\hline 4 & 100,0 & 99,75 & 99,75 & \multirow{3}{*}{0,3} \\
\hline 5 & 100,0 & 99,30 & 99,30 & \\
\hline 6 & 100,0 & 99,30 & 99,30 & \\
\hline 7 & 120,0 & 118,54 & 98,78 & \multirow{3}{*}{0,4} \\
\hline 8 & 120,0 & 119,26 & 99,38 & \\
\hline 9 & 120,0 & 119,51 & 99,59 & \\
\hline \multicolumn{4}{|c|}{ ма концентраційними рівнями } & 0,81 \\
\hline
\end{tabular}

Примітка:

$X_{i}$ та $Y_{i}$ - нормалізовані значення «знайдено/введено»;

$Z_{i}$ - відношення «знайдено/введено» енісаміуму йодиду, \%;

$C_{i}$ - концентрація енісаміуму йодиду в $i$-ому аналізованому розчині;

$C_{s t}$ - концентрація енісаміуму йодиду в розчині порівняння;

$A_{i}$ - абсорбція для $i$-того аналізованого розчину;

$A_{\text {st }}-$ абсорбція для розчину порівняння.

Також встановлено, що зміна довжини хвилі детектування (від 265 до 269 нм) так само, як і застосування компенсаційного розчину, в якості якого використовували 0,09 та 0,11 М розчин хлористоводневої кислоти, не має значного впливу на результати аналізу.

Відхилення співвідношень абсорбції розчину порівняння та випробовуваного розчину у всіх експериментах щодо робасності не перевищувало 1,0 \%.

Розрахунок сумарної невизначеності операції пробопідготовки було проведено, виходячи з даних, що наведено в таблиці 6 .

Розрахунок сумарної невизначеності $\Delta \mathrm{Sp}$ для розчину порівняння наведено нижче.

$$
\Delta S p=\sqrt{0,1^{2}+0,12^{2}+0,98^{2}+0,12^{2}}=1,00 \%
$$

Оскільки невизначеність пробопідготовки для випробовуваного розчину буде така ж, як і для розчину порівняння (однакова пробопідготовка), то сумарна прогнозована невизначеність пробопідготовки становить:

$$
\sqrt{1,00^{2}+1,00^{2}}=1,41 \%
$$

Примітка. Невизначеність пробопідготовки перевищує допустимий рівень, оскільки прийнятний рівень становить $0,32 \times \Delta_{A s}=0,32 \times 1,6=0,51 \%(1,41$ $>0,51)$.

Відповідно до ДФУ, у випадку, коли не виконується наведене вище співвідношення, то використовують критерій незначущості цієї систематичної похибки порівняно з максимально припустимою невизначеністю аналізу [10].

Прогноз загальної невизначеності аналізу $\Delta_{A s}$ проводили за наступним співвідношенням:

$$
\Delta_{A s}^{2}=\Delta_{S P}^{2}+\Delta_{F A O}^{2}
$$

$\Delta_{\mathrm{SP}}-$ невизначеність пробопідготовки;

$\Delta_{\text {FAO }}-$ невизначеність кінцевої аналітичної операції (в даному випадку - спектрофротометрії).

$\Delta_{\text {FAO }}$ розраховується із співвідношення:

$$
\Delta_{F A O}=2 \cdot S_{s p}
$$

\begin{tabular}{|c|c|c|}
\hline Операція & Дані для розрахунку & Невизначеність, \% \\
\hline \multicolumn{3}{|c|}{ Розчин порівняння } \\
\hline Зважування стандартного зразка & 200 мг (з точністю до \pm 0,0001 г) & 0,1 \\
\hline Доведення до об'єму 100 мл & 100 & 0,12 \\
\hline Відбір аліквоти піпеткою Мора & 1,0 & 0,98 \\
\hline Доведення до об'єму мірної колби & 100 & 0,12 \\
\hline
\end{tabular}

При розрахунку повної невизначеності аналізу необхідно використовувати максимально допустимі ве-

Таблиця 6. Розрахунок невизначеності пробопідготовки

ISSN 2312-0967. Фармацевтичний часопис. 2017. № 2 
личини $S_{s p}$. Відповідно до характеристики спектрофотометра Specord 200 «Analytik Jena», Німеччина, величина $S_{s p}$ не перевищує 0,20\%.

$$
\Delta_{F A O}=2 \cdot 0,2=0,40
$$

Тоді, $\Delta_{\text {As }}$ складає $\sqrt{1,41^{2}+0,40^{2}}=1,47 \%<1,60 \%$.

Таким чином, методика коректна та може відтворюватися в інших лабораторіях 3 необхідною точністю.

Висновки. Розроблено методику кількісного визначення енісаміуму йодиду в лікарській формі капсули тверді із застосуванням спектрофротометричного методу визначення при довжині хвилі 267 нм.

Проведено валідацію аналітичної методики, якою підтверджено специорічність, лінійність, правиль- ність, збіжність, робасність та внутрішньолабораторну прецизійність розробленої методики.

Встановлено, що повна невизначеність аналітичної методики відповідає вимогам ДФУ.

Коефіцієнт кореляції (r) між введеним та знайденим значенням для енісаміуму йодиду становить 0,99996, (відносний довірчий інтервал 0,23 \%).

Доведено, що розчин порівняння та випробовуваний розчин стабільні протягом 48 годин.

Таким чином, спектрофотометрична методика кількісного визначення може бути використана для контролю якості капсул енісаміуму йодиду.

Подяка. Автори висловлюють подяку А. М. Стельмаху та В. Д. Корзуненку за плідну дискусію та цінні поради до статті.

\title{
РАЗРАБОТКА И ВАЛИДАЦИЯ СПЕКТРОФОТОМЕТРИЧЕСКОЙ МЕТОДИКИ КОЛИЧЕСТВЕННОГО ОПРЕДЕЛЕНИЯ ЭНИСАМИУМА ИОДИДА В КАПСУЛАХ
}

\section{А. В. Бурмака, С. Н. Гуреева, В. М. Маргитич}

\author{
ПАО Фармак, Киев \\ o.burmaka@farmak.ua
}

Цель работы. Разработать методику количественного определения энисамиума иодида в капсулах с применением метода абсорбционной спектрофотометрии в ультрафиолетовой области.

Материалы и методы. Использован стандартный образец энисамиума иодида и образец готовой лекарственной фрормы производства ПАО «Фармак». В ходе работы было установлено оптимальную рабочую концентрацию энисамиума иодида 0,02 мг/мл. Исследование проводили с использованием спектрофротометра «Specord 250 Plus». Результаты и обсуждение. Показано, что оптимальная длина волны при определении составляет 267 нм. Изучены валидационные характеристики методики в диапазоне 0,016-0,024 мг/мл (80-120 \%): специсричность, правильность, прецизионность, линейность, диапазон применения, робастность, внутрилабораторная прецизионность в соответствии с рекомендациями Международной конференции по гармонизации.

Коэффрициент корреляции между введенным и найденным значением для энисамиума иодида составляет $r=0,99996$, а относительный доверительный интервал $\Delta_{z}=0,23 \%$.

Подтверждена стабильность растворов при комнатной температуре на протяжении 48 часов.

Выводы. Разработана спектрофотометрическая методика количественного определения энисамиума иодида в капсулах, экспериментально доказано, что она пригодна для контроля качества капсул энисамиума иодида.

Ключевые слова: энисамиум иодид; капсулы; количественное определение; метод спектросротометрии; валидация.

\section{DEVELOPMENT AND VALIDATION OF THE SPECTROPHOTOMETRIC METHOD OF QUANTITATIVE DETERMINATION OF ENISAMIUM IODIDE IN CAPSULES}

\section{O. V. Burmaka, S. M. Gureyeva, V. M. Margitich}

Farmak JSC, Kyiv

o.burmaka@farmak.ua

The aim of the work. The work is devoted to development of the method for quantitative determination of enisamium iodide in capsules using the method of ultraviolet absorption spectrophotometry.

Materials and Methods. The reference standard of enisamium iodide and the sample of finished drug product produced by Farmak JSC were used. The working concentration of enisamium iodide $0.02 \mathrm{mg} / \mathrm{ml}$ was established. The study was carried out using the spectrophotometer «Specord 250 Plus».

Results and Discussion. The optimal wavelength for determination was found to be $267 \mathrm{~nm}$.

ISSN 2312-0967. Pharmaceutical review. 2017. № 2 


\begin{abstract}
Analysis of drugs
The method validation characteristics such as specificity, accuracy, precision, linearity, range, robustness, intermediate precision were studied in accordance with recommendations of the International Conference on Harmonization in the range of $0.016-0.024 \mathrm{mg} / \mathrm{ml}(80-120 \%)$.

The correlation coefficient between the fitted and observed values for enisamium iodide was high $(r=0.99996)$, at the same time the relative confidence interval was low $\left(\Delta_{z}=0.23 \%\right)$.

Solutions were confirmed to be stable for 48 hours at the room temperature.

Conclusions. The spectrophotometric method of enisamium iodide assay in capsules was developed, experimentally was established that the described method can be used for quality control of enisamium iodide capsules.
\end{abstract}

Key words: enisamium iodide; capsules; assay; spectrophotometry; validation.

\section{Список літератури}

1. Antiviral activity of enisamium against influenza viruses in differentiated normal human bronchial epithelial cells / D. Boltz, X. Peng, M. Muzzio [et al.] // The 3rd Antivirals Congress, 12-14 October 2014. - Amsterdam, 2014. - P. 46.

2. Противовирусная активность энисамиума (Амизона) в отношении вирусов гриппа в дифрференцированных нормальных клетках эпителия бронхов человека / Д. Больц, С. Пен, М. Муззио [и др.] // Русский медицинский журнал. - 2015. - № 2. - С. 72-74.

3. Specifications and control tests on the finished product / Guideline 3AQ11a of European Medicines Agency. - London, 1992. - P. 83-94.

4. Про затвердження Порядку проведення експертизи реєстраційних матеріалів на лікарські засоби, що подаються на державну реєстрацію (перереєстрацію), а також експертизи матеріалів про внесення змін до реєстраційних матеріалів протягом дії реєстраційного посвідчення : наказ МОЗ України від 26.08.2005 № 426 [Електронний ресурс: http://www.dec.gov.ua/index. php/ ua/351-normativno-pravovi-akti/uvaga/931-nakaz-mozukrajini-vid-26-08-05-426].

5. Validation of analytical procedures: text and methodology / ICH Expert Working Group. ICH Harmonised Tripartite Guideline Q2 (R1). Step 4 version. - Guideline of European Medicines Agency. - London, 1995. - 13 p.

\section{References}

1. Boltz D, Peng X, Muzzio M, Dash P, Thomas P, Mehta $R$, et al. Antiviral activity of enisamium against influenza viruses in differentiated normal human bronchial epithelial cells. Proceedings of the 3rd Antivirals Congress; 2014 Oct 12-14; Amsterdam, Netherlands.

2. Bolts $D$, Pen S, Muzzio M, Dash P, Tomas P, Mekhta $R$, et al. Antiviral activity of enisamium (Amizon) against influenza viruses in differentiated normal human bronchial epithelial cells. [Противовирусная активность энисамиума (Амизона) в отношении вирусов гриппа в диффреренцированных нормальных клетках эпителия бронхов человека]. Russkiy meditsinskiy zhurnal. 2015;2:72-4. Russian.

3. Guideline 3AQ11a of European Medicines Agency. Specifications and control tests on the finished product. London; 1992. p. 83-94.

4. Order of the Ministry of Health of Ukraine dated
6. Державна Фармакопея України / Державне підприємство «Український науковий срармакопейний центр якості лікарських засобів». - 2-е вид. - Харків : Державне підприємство «Український науковий фрармакопейний центр якості лікарських засобів», 2015. - T. 1. -1128 c.

7. European Pharmacopoeia / European Directorate for the Quality of Medicines \& Health Care, 2016. - $9^{\text {th }}$ edition, Vol. 1. -1615 p.

8. Аналитическая химия в создании, стандартизации и контроле качества лекарственных средств / под ред. чл. кор. НАН Украины В. П. Георгиевского. - Харьков : НТМП, 2011. - Т. 1. - 96 с.

9. Державна Фармакопея України / Державне підприємство «Український науковий фрармакопейний центр якості лікарських засобів». - 2-е вид. - Харків : Державне підприємство «Український науковий фрармакопейний центр якості лікарських засобів», 2015. - Т. 1. - C. 891-893.

10. Державна Фармакопея України / Державне підприємство «Український науковий фрармакопейний центр якості лікарських засобів». - 2-е вид. - Харків : Державне підприємство «Український науковий фармакопейний центр якості лікарських засобів», 2015. - T. 1. - C. 924-925.

26.08.2005 № 426. Procedure for conducting expert evaluation of materials pertinent to medicinal products, which are submitted for state registration (re-registration) and expert evaluation of materials about introduction of changes to the registration documents during the validity period of registration certificate. Available from: http://www.dec.gov.ua/site/ files/home/420/p.pdf.

5. Guideline Q2 (R1) of European Medicines Agency. Validation of analytical procedures: text and methodology. London; 1995. p. 13.

6. Ukrainian Scientific Pharmacopoeial Center for Quality of Medicines. State Pharmacopoeia of Ukraine. [Державна Фармакопея Україна]. 2nd ed. Vol. 1. Kharkiv: Ukrainian Scientific Pharmacopoeial Center for Quality of Medicines; 2015. Ukrainian.

7. European Directorate for the Quality of Medicines \& Health Care. European Pharmacopoeia. 9th ed. Vol. 1.

ISSN 2312-0967. Фармацевтичний часопис. 2017. № 2 
Strasbourg: EDQM; 2016.

8. Georgievskiy VP, editor. Analytical chemistry in the creation, standardization and quality control of medicines. [Аналитическая химия в создании, стандартизации и контроле качества лекарственных средств]. Vol. 1. Kharkov: edition HTMT; 2011. p. 96. Russian.

9. Ukrainian Scientific Pharmacopoeial Center for Quality of Medicines. State Pharmacopoeia of Ukraine. [Державна
Фармакопея України]. 2nd ed. Vol. 1. Kharkiv: Ukrainian Scientific Pharmacopoeial Center for Quality of Medicines; 2015. p. 891-3. Ukrainian.

10. Ukrainian Scientific Pharmacopoeial Center for Quality of Medicines. State Pharmacopoeia of Ukraine. [Державна Фармакопея України]. 2nd ed. Vol. 1. Kharkiv: Ukrainian Scientific Pharmacopoeial Center for Quality of Medicines; 2015. p. 924-5. Ukrainian. 